Keywords: DWPF, fissile, WAPS, density, SB8

Retention: Permanent

\title{
EVALUATION OF GLASS DENSITY TO SUPPORT THE ESTIMATION OF FISSILE MASS LOADINGS FROM IRON CONCENTRATIONS IN SB8 GLASSES
}

T.B. Edwards

D.K. Peeler

W.K. Kot

H. Gan

I.L. Pegg

April 2013

Savannah River National Laboratory Savannah River Nuclear Solutions

Aiken, SC 29808

Prepared for the U.S. Department of Energy under contract number DE-AC09-08SR22470.

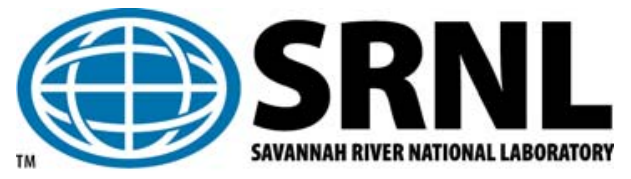




\section{DISCLAIMER}

This work was prepared under an agreement with and funded by the U.S. Government. Neither the U.S. Government or its employees, nor any of its contractors, subcontractors or their employees, makes any express or implied:

1. warranty or assumes any legal liability for the accuracy, completeness, or for the use or results of such use of any information, product, or process disclosed; or

2. representation that such use or results of such use would not infringe privately owned rights; or

3. endorsement or recommendation of any specifically identified commercial product, process, or service.

Any views and opinions of authors expressed in this work do not necessarily state or reflect those of the United States Government, or its contractors, or subcontractors.

\section{Printed in the United States of America}

Prepared for

U.S. Department of Energy 


\section{REVIEWS AND APPROVALS}

AUTHORS:

T.B. Edwards, Applied Computational Engineering and Statistics

Date

D.K. Peeler, Process Technology Programs

Date

W.K. Kot, Vitreous State Laboratory

Date

H. Gan, Vitreous State Laboratory

Date

I.L. Pegg, Vitreous State Laboratory

Date

TECHNICAL REVIEWS:

K.M. Fox, Engineering Process Development

Date

(Document Review per E7, 2.60)

E.P. Shine, Applied Computational Engineering and Statistics

Date

(Document Review per E7, 2.60)

\section{APPROVALS:}

D.R. Click, Manager, Process Technology Programs

Date

S. L. Marra, Manager,

Date

Environmental \& Chemical Process Technology Research Programs

E.J. Freed, Manager

Date

Waste Solidification Engineering 


\section{TABLE OF CONTENTS}

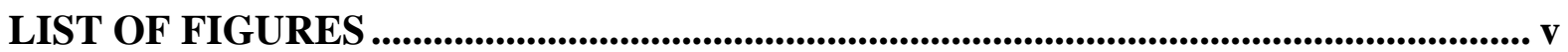

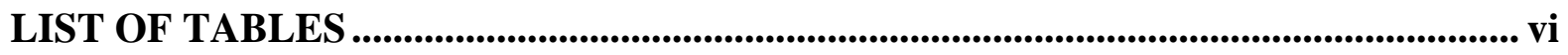

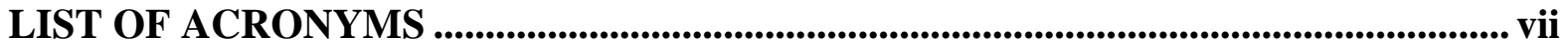

EXECUTIVE SUMMARY ..........................................................................................vviii

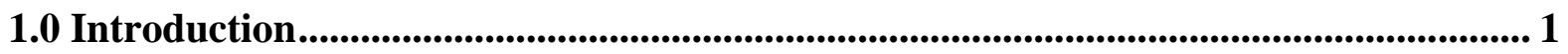

2.0 Experimental: SB8 Glass Density Determination .................................................... 2

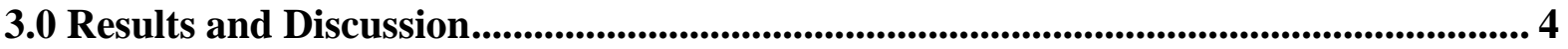

4.0 Summary............................................................................................................................................... 10

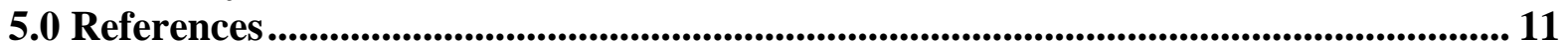




\section{LIST OF FIGURES}

Figure 1. Measured Densities by Glass ID Grouped by Description/Type of Composition and \%WL.

Figure 2. Density as a Function of Waste Loading for the Frit 803 - Nominal SB8 Variability Study Glasses.

Figure 3. Histogram and Descriptive Statistics for the Densities of SB8 VS Glasses at 36\% WL. 


\section{LIST OF TABLES}

Table 1. Individual and Average Density Measurements for the SB8 VS Glasses and for the SRM1827a and SRM1826b NIST Standard Glasses.

Table 2. $\quad$ Average Density Measurement for Each SB8 Glass.

Table 3. Predicted Densities as a Function of WL for the Linear Fit with 99\%/99\% UTLs. 


\section{LIST OF ACRONYMS}

$\begin{array}{ll}\text { ARP } & \text { Actinide Removal Process } \\ \text { ASTM } & \text { American Society for Testing and Materials } \\ \text { CUA } & \text { The Catholic University of America } \\ \text { DOE-SR } & \text { Department of Energy - Savannah River } \\ \text { DWPF } & \text { Defense Waste Processing Facility } \\ \text { EVs } & \text { Extreme Vertices } \\ \text { HLW } & \text { High Level Waste } \\ \text { NIST } & \text { National Institute of Standards and Technology } \\ \text { RMSE } & \text { Root Mean Square Error } \\ \text { SB5 } & \text { Sludge Batch 5 } \\ \text { SB6 } & \text { Sludge Batch 6 } \\ \text { SB7a } & \text { Sludge Batch 7a } \\ \text { SB7b } & \text { Sludge Batch 7b } \\ \text { SB8 } & \text { Sludge Batch 8 } \\ \text { SME } & \text { Slurry Mix Evaporator } \\ \text { SO } & \text { Sludge Only } \\ \text { SRNL } & \text { Savannah River National Laboratory } \\ \text { SRR } & \text { Savannah River Remediation } \\ \text { UTL } & \text { Upper Tolerance Limit } \\ \text { VS } & \text { Variability Study } \\ \text { VSL } & \text { Vitreous State Laboratory } \\ \text { WAPS } & \text { Waste Acceptance Product Specifications } \\ \text { WL } & \text { Waste Loading } \\ & \end{array}$




\section{EXECUTIVE SUMMARY}

The Department of Energy - Savannah River (DOE-SR) has provided direction to Savannah River Remediation (SRR) to maintain fissile concentration in glass below $897 \mathrm{~g} / \mathrm{m}^{3}$. In support of that guidance, the Savannah River National Laboratory (SRNL) provided a technical basis and a supporting Microsoft ${ }^{\circledR}$ Excel $^{\circledR}$ spreadsheet for the evaluation of fissile loading in Sludge Batch 5 (SB5), Sludge Batch 6 (SB6), Sludge Batch 7a (SB7a), and Sludge Batch 7b (SB7b) glass based on the iron $(\mathrm{Fe})$ concentration in glass as determined by the measurements from the Slurry Mix Evaporator (SME) acceptability analysis. SRR has since requested that the necessary density information be provided to allow SRR to update the Excel ${ }^{\circledR}$ spreadsheet so that it may be used to maintain fissile concentration in glass below $897 \mathrm{~g} / \mathrm{m}^{3}$ during the processing of Sludge Batch 8 (SB8).

One of the primary inputs into the fissile loading spreadsheet includes an upper bound for the density of SB8-based glasses. Based on the measured density data of select SB8 variability study glasses, it is recommended that SRR utilize the 99\%/99\% Upper Tolerance Limit (UTL) density values given below as upper bounds for the densities of the SB8 glass system at the waste loadings (WLs) as indicated. Thus, these bounding density values are to be used to assess the fissile concentration in this glass system. It should be noted that no changes are needed to the underlying structure of the Excel ${ }^{\circledR}$ based spreadsheet to support fissile assessments for SB8. However, SRR should update the other key inputs to the spreadsheet that are based on fissile and Fe concentrations reported from the SB8 Waste Acceptance Product Specification (WAPS) sample.

\begin{tabular}{||c|c||}
\hline WL & $\begin{array}{c}\mathbf{9 9 \% / 9 9 \% ~ U T L ~ f o r ~} \\
\text { Glass Density }\left(\mathbf{g} / \mathbf{c m}^{\mathbf{3}}\right)\end{array}$ \\
\hline 32 & 2.779 \\
\hline 34 & 2.777 \\
\hline 36 & 2.786 \\
\hline 38 & 2.810 \\
\hline 40 & 2.843 \\
\hline
\end{tabular}




\subsection{INTRODUCTION}

The Department of Energy - Savannah River (DOE-SR) previously provided direction to Savannah River Remediation (SRR) to maintain fissile concentrations below $897 \mathrm{~g} / \mathrm{m}^{3}$ in the high level waste (HLW) glass produced by the Defense Waste Processing Facility (DWPF). ${ }^{1}$ To support DWPF in meeting that directive starting with the processing of Sludge Batch 5 (SB5), the Savannah River National Laboratory (SRNL) developed a technical basis and an associated Microsoft ${ }^{\circledR}$ Excel $^{\circledR}$ spreadsheet that facilitates the evaluation of fissile loading of a glass product based on the iron (Fe) concentration in the glass as determined by the measurements from the Slurry Mix Evaporator (SME) acceptability analysis. ${ }^{2}$ SRNL provided the necessary information to allow SRR to update the Excel ${ }^{\circledR}$ spreadsheet so that it may be used to maintain fissile concentration in glass below $897 \mathrm{~g} / \mathrm{m}^{3}$ during the processing of Sludge Batch 6 (SB6) ${ }^{3}$, Sludge Batch 7a (SB7a) ${ }^{4}$, and Sludge Batch 7b (SB7b) ${ }^{5}$. SRR has since requested that information on glass densities be provided to support fissile assessments for the glass system associated with the processing of Sludge Batch 8 (SB8). ${ }^{6}$

Insight into the density of SB8 glasses is to be based on the glasses resulting from the SB8 variability study (VS) ${ }^{7-9}$. Twenty two glasses were selected for the SB8 VS. Twelve of the SB8 VS glasses were determined by combining an optimally selected set of 12 Extreme Vertices (EVs) from the sludge composition region of interest (with each of these sludge compositions being combined with Frit 803 at $36 \%$ waste loading (WL)). Five glasses were defined by combining the nominal sludge only (SO) composition with Frit 803 at WLs of 32, 34, 36, 38, and 40\% WL. The remaining five SB8 VS glasses were based on the combination of the nominal coupled operations composition, reflecting an Actinide Removal Process (ARP) stream of 1050 gallons, with Frit 803 at WLs of 32, 34, 36, 38, and $40 \% \mathrm{WL}$. These glasses were fabricated and densities measured by the Vitreous State Laboratory (VSL) of The Catholic University of America (CUA) in accordance with the test plan supporting this work. ${ }^{10}$

The purpose of this technical report is to present the density measurements that were conducted for the SB8 VS glasses and to perform a statistical evaluation of these measurements to provide a bounding density value that may be used as input to the Excel ${ }^{\circledR}$ spreadsheet to be employed by SRR to maintain the fissile concentration in its SB8 glass below $897 \mathrm{~g} / \mathrm{m}^{3}$. It should be noted that no changes are needed to the underlying structure of the Excel ${ }^{\circledR}$-based spreadsheet to support fissile assessments for SB8. JMP Version 9.0.0 was used to support this analysis. ${ }^{11}$ 


\subsection{EXPERIMENTAL: SB8 GLASS DENSITY DETERMINATION}

All of the density measurements for this study were performed using the VSL procedure "Test Method for Density of Glass by Buoyancy at Room Temperature," " which is based on the American Society for Testing and Materials (ASTM) method C693-93 "Standard Test Method for Density of Glass by Buoyancy." Duplicate density measurements were performed on each glass. Table 1 provides, in the order recorded, the individual and average density measurements for each of the SB8 VS glasses. Also included in Table 1 are the density measurements of the SRM1827a and SRM1826b glasses, which are National Institute of Standards and Technology (NIST) traceable standard reference glasses. $^{13,14}$ The SRM1827a density results indicate no significant issues with the measurement technique. More specifically, the reported density of the SRM1827a glass (from NIST) is $3.593014 \pm 0.000025 \mathrm{~g} / \mathrm{cm}^{3}$. The average measured density in this testing for this standard glass was $3.59267 \mathrm{~g} / \mathrm{cm}^{3}$, a difference of $\sim 0.0003 \mathrm{~g} / \mathrm{cm}^{3}$ from the reference value for the standard. In addition, the SRM1827b density results indicate no significant issues with the measurement technique. More specifically, the reported density of the SRM1827b glass (from NIST) is $2.548668 \pm$ $0.000032 \mathrm{~g} / \mathrm{cm}^{3}$. The average measured density in this testing for this standard glass was 2.54933 $\mathrm{g} / \mathrm{cm}^{3}$, a difference of $\sim 0.0007 \mathrm{~g} / \mathrm{cm}^{3}$ from the reference value for the standard. 
Table 1. Individual and Average Density Measurements for the SB8 VS Glasses and for the SRM1827a and SRM1826b NIST Standard Glasses.

\begin{tabular}{|c|c|c|c|c|}
\hline & & 1st Read & 2nd Read & Average \\
\hline $\begin{array}{l}\text { ES/VSL } \\
\text { Glass ID }\end{array}$ & Description & Density $\left(\mathrm{g} / \mathrm{cm}^{3}\right)$ & Density $\left(\mathrm{g} / \mathrm{cm}^{3}\right)$ & Density $\left(\mathrm{g} / \mathrm{cm}^{3}\right)$ \\
\hline SRM 1826b & Standard & 2.550 & - & 2.550 \\
\hline SRM1827a & Standard & 3.592 & - & 3.592 \\
\hline VSL-SB8-20 & D-Opt EV, 36\% WL & 2.723 & 2.722 & 2.723 \\
\hline VSL-SB8-04 & 1050 gallons ARP, 34\% WL & 2.686 & 2.688 & 2.687 \\
\hline VSL-SB8-09 & Sludge-only, $40 \% \mathrm{WL}$ & 2.739 & 2.741 & 2.740 \\
\hline VSL-SB8-03 & Sludge-only, 34\% WL & 2.693 & 2.691 & 2.692 \\
\hline VSL-SB8-07 & Sludge-only, 38\% WL & 2.721 & 2.723 & 2.722 \\
\hline VSL-SB8-15 & D-Opt EV, 36\% WL & 2.681 & 2.680 & 2.681 \\
\hline SRM 1826b & Standard & 2.547 & - & 2.547 \\
\hline SRM 1827a & Standard & 3.596 & - & 3.596 \\
\hline VSL-SB8-11 & D-Opt EV, 36\% WL & 2.704 & 2.703 & 2.704 \\
\hline VSL-SB8-22 & D-Opt EV, 36\% WL & 2.698 & 2.701 & 2.700 \\
\hline VSL-SB8-19 & D-Opt EV, 36\% WL & 2.703 & 2.702 & 2.703 \\
\hline VSL-SB8-16 & D-Opt EV, 36\% WL & 2.707 & 2.707 & 2.707 \\
\hline VSL-SB8-21 & D-Opt EV, 36\% WL & 2.708 & 2.710 & 2.709 \\
\hline SRM 1826b & Standard & 2.549 & - & 2.549 \\
\hline SRM 1827a & Standard & 3.591 & - & 3.591 \\
\hline VSL-SB8-05 & Sludge-only, 36\% WL & 2.707 & 2.705 & 2.706 \\
\hline VSL-SB8-14 & D-Opt EV, 36\% WL & 2.711 & 2.710 & 2.711 \\
\hline VSL-SB8-13 & D-Opt EV, 36\% WL & 2.698 & 2.700 & 2.699 \\
\hline VSL-SB8-10 & 1050 gallons ARP, $40 \% \mathrm{WL}$ & 2.734 & 2.734 & 2.734 \\
\hline VSL-SB8-02 & 1050 gallons ARP, $32 \% \mathrm{WL}$ & 2.673 & 2.673 & 2.673 \\
\hline VSL-SB8-17 & D-Opt EV, 36\% WL & 2.702 & 2.701 & 2.702 \\
\hline SRM 1826b & Standard & 2.550 & - & 2.550 \\
\hline SRM 1827a & Standard & 3.592 & - & 3.592 \\
\hline VSL-SB8-08 & 1050 gallons ARP, 38\% WL & 2.718 & 2.719 & 2.719 \\
\hline VSL-SB8-18 & D-Opt EV, 36\% WL & 2.700 & 2.701 & 2.701 \\
\hline VSL-SB8-01 & Sludge-only, 32\% WL & 2.674 & 2.675 & 2.675 \\
\hline VSL-SB8-12 & D-Opt EV, 36\% WL & 2.721 & 2.718 & 2.720 \\
\hline VSL-SB8-06 & 1050 gallons ARP, 36\% WL & 2.704 & 2.705 & 2.705 \\
\hline SRM 1826b & Standard & 2.550 & - & 2.550 \\
\hline SRM 1827a & Standard & 3.592 & - & 3.592 \\
\hline SRM 1826b & Standard & 2.550 & - & 2.550 \\
\hline SRM 1827a & Standard & 3.593 & - & 3.593 \\
\hline
\end{tabular}




\subsection{RESULTS AND DISCUSSION}

One of the primary factors affecting the density of the glass waste-form for a sludge-frit system is its WL. In addition, there are two other sources of variation in the density measurements of the study glasses that are of interest: (1) the repeatability of the measurement process utilized for assessing glass density (i.e., how repeatable is the density measurement for a specific glass) and (2) differences in density from one glass to another (both representing the same WL) due to compositional differences in sludge (e.g., with and without including the ARP stream).

The sources of variation are investigated in Figure 1, which plots the measured density values for each study glass with the glasses grouped as described above for the SB8 VS. ${ }^{7,8}$ Specifically, three groupings (i.e., EVs, ARP, and SO) are shown.

With respect to the issue of repeatability of the measurements for a given glass, the overlap (or small variation) of the replicate data for each glass demonstrates that the density measurements are very reproducible. Since the density of interest is the true density of the glass produced by DWPF, the replication error (the variation due to the measurement process) for a single glass may be considered as a nuisance factor while the differences in the densities of the glass from one SME batch to the glass from another SME batch must be understood. 


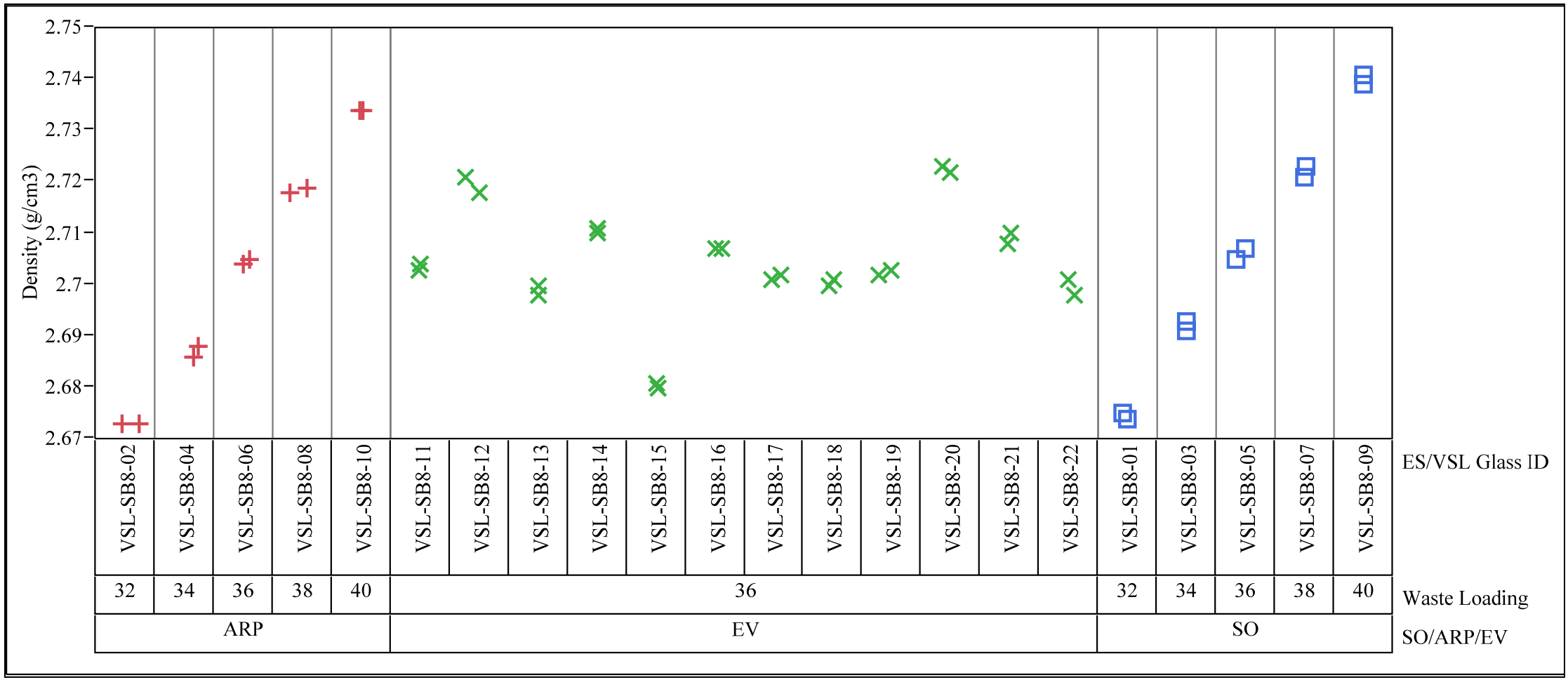

Figure 1. Measured Densities by Glass ID Grouped by Description/Type of Composition and \%WL. 
Table 2 provides the average density results for each of the SB8 glasses with descriptions that identify the glasses from the EV compositions and those based upon the nominal sludge composition (sludgeonly or ARP) combined with Frit 803 at a targeted WL.

Table 2. Average Density Measurement for Each SB8 Glass.

\begin{tabular}{|c|c|c|}
\hline & & Average \\
\hline $\begin{array}{l}\text { ES/VSL } \\
\text { Glass ID }\end{array}$ & Description & Density $\left(\mathrm{g} / \mathrm{cm}^{3}\right)$ \\
\hline VSL-SB8-01 & Sludge-only, 32\% WL & 2.675 \\
\hline VSL-SB8-03 & Sludge-only, 34\% WL & 2.692 \\
\hline VSL-SB8-05 & Sludge-only, 36\% WL & 2.706 \\
\hline VSL-SB8-07 & Sludge-only, 38\% WL & 2.722 \\
\hline VSL-SB8-09 & Sludge-only, 40\% WL & 2.740 \\
\hline VSL-SB8-02 & 1050 gallons ARP, 32\% WL & 2.673 \\
\hline VSL-SB8-04 & 1050 gallons ARP, 34\% WL & 2.687 \\
\hline VSL-SB8-06 & 1050 gallons ARP, 36\% WL & 2.705 \\
\hline VSL-SB8-08 & 1050 gallons ARP, 38\% WL & 2.719 \\
\hline VSL-SB8-10 & 1050 gallons ARP, 40\% WL & 2.734 \\
\hline VSL-SB8-11 & $\mathrm{EV}, 36 \% \mathrm{WL}$ & 2.704 \\
\hline VSL-SB8-12 & $\mathrm{EV}, 36 \% \mathrm{WL}$ & 2.720 \\
\hline VSL-SB8-13 & $\mathrm{EV}, 36 \% \mathrm{WL}$ & 2.699 \\
\hline VSL-SB8-14 & $\mathrm{EV}, 36 \% \mathrm{WL}$ & 2.711 \\
\hline VSL-SB8-15 & $\mathrm{EV}, 36 \% \mathrm{WL}$ & 2.681 \\
\hline VSL-SB8-16 & $\mathrm{EV}, 36 \% \mathrm{WL}$ & 2.707 \\
\hline VSL-SB8-17 & $\mathrm{EV}, 36 \% \mathrm{WL}$ & 2.702 \\
\hline VSL-SB8-18 & $\mathrm{EV}, 36 \% \mathrm{WL}$ & 2.701 \\
\hline VSL-SB8-19 & $\mathrm{EV}, 36 \% \mathrm{WL}$ & 2.703 \\
\hline VSL-SB8-20 & $\mathrm{EV}, 36 \% \mathrm{WL}$ & 2.723 \\
\hline VSL-SB8-21 & EV, 36\% WL & 2.709 \\
\hline VSL-SB8-22 & EV, 36\% WL & 2.700 \\
\hline
\end{tabular}

Figure 2 shows the relationships between density and WL for the nominal SO and ARP VS glasses. As expected, as WL increases, the density of these glasses increases for both sludge compositions with the SO densities being consistently larger than those of the ARP glasses. Since determining an upper bound for the density values at WLs of interest is the objective of this investigation, SO glasses will be used to establish the relationship between density and WL. 


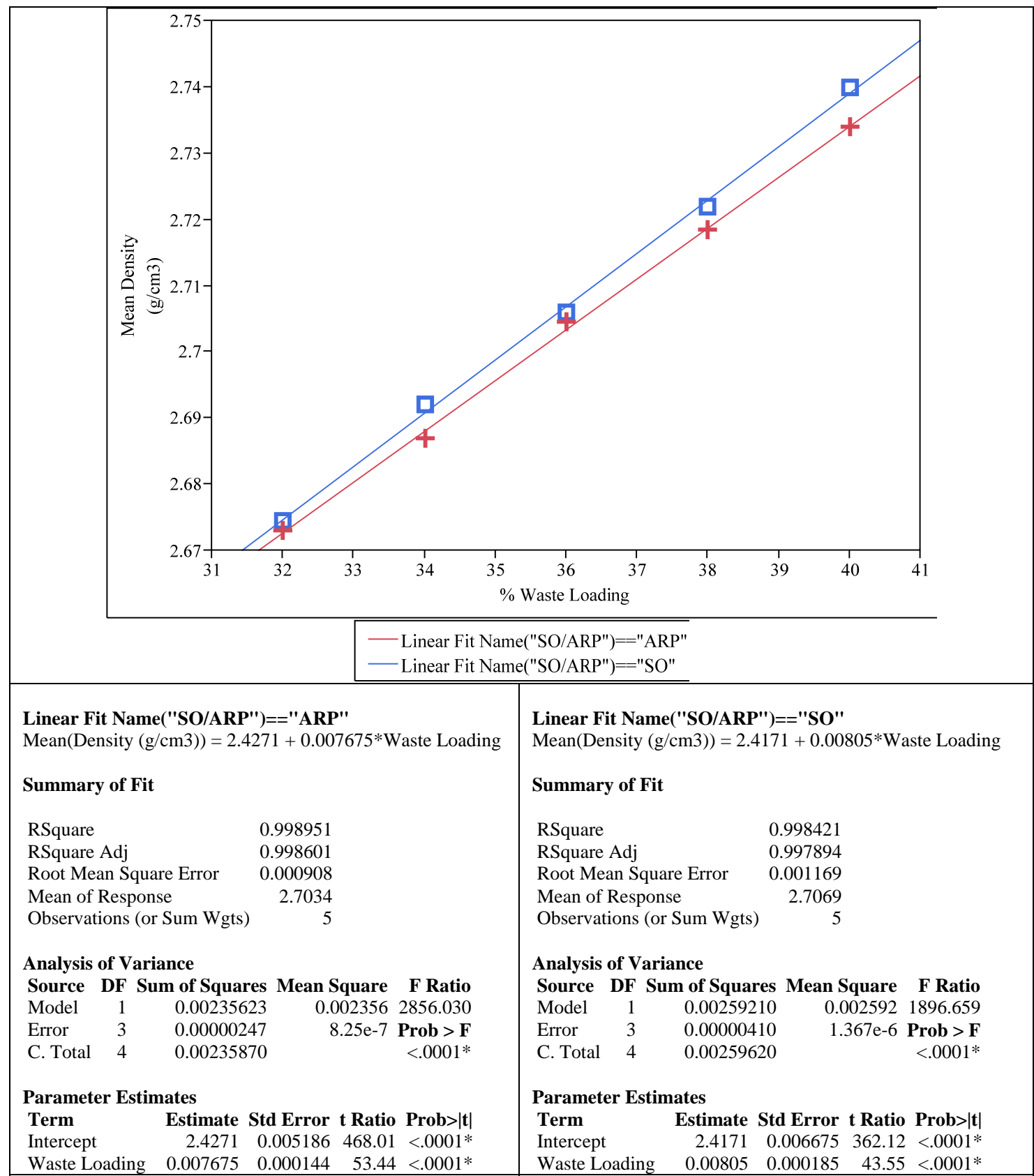

Figure 2. Density as a Function of Waste Loading for the Frit 803 - Nominal SB8 Variability Study Glasses.

It is recognized that the SO linear regression provided in Figure 2 is based on a nominal SB8 compositional projection without accounting for potential waste composition variation. More specifically, the density data and linear fit reported above were based on SB8 SO glasses using a nominal sludge projection that did not account for possible sludge variation at a fixed WL. Thus, the determination of an upper bound for the density of SB8 glasses at a given WL must address two sources of uncertainty: the uncertainty of the linear relationship between glass density and WL in Figure 2, and the effects of sludge variation on glass density. 
The uncertainty of the linear fit is addressed using an upper tolerance limit (UTL) approach described by Miller. ${ }^{15}$ This approach has been previously used by SRNL to support previous sludge batch density assessments. ${ }^{2-5}$ The resulting $100(1-\alpha) \% / 100\left(1-\alpha_{0}\right) \%$ UTL $^{\mathrm{a}}$ is for $100\left(1-\alpha_{0}\right) \%$ of all density values of the SB8 glasses at a confidence of $100(1-\alpha) \%$ for each and every WL within the interval from 32 to $40 \%$ :

$$
\mathrm{UTL} \rho_{\mathrm{i}}=\mathrm{b}+\mathrm{m} \cdot \mathrm{WL}_{\mathrm{i}}+\mathrm{s}\left\{\sqrt{\mathrm{pF}(\mathrm{p}, \mathrm{n}-\mathrm{p})} \sqrt{\underline{\mathrm{c}}_{0}\left(\mathbf{X}^{\mathrm{T}} \mathbf{X}\right)^{-1} \underline{\mathrm{c}}_{0}^{\mathrm{T}}}+\mathrm{z}_{1-\alpha_{0}} \sqrt{\frac{\mathrm{n}-\mathrm{p}}{\chi_{\alpha / 2, \mathrm{n}-\mathrm{p}}^{2}}}\right\}
$$

where

- $\quad \mathrm{UTL} \rho_{\mathrm{i}}$ equals the upper tolerance interval for the glass density at $\mathrm{WL}_{\mathrm{i}}$,

- the estimated slope and intercept of the SO fitted model are $\mathrm{m}$ and b, respectively, (where $\mathrm{m}$ $=0.00805$ and $\mathrm{b}=2.4171$ ),

- $\quad \mathrm{s}$ is the root mean square error (RMSE) for the fitted model for density as a function of WL (the value is given by 0.001169 ),

- $F_{\alpha}(p, n-p)$ is the $100(1-\alpha) \%$ quantile of the $F$ distribution, which depends on $n=5$ (i.e., the number of data points on which this $p$-parameter $(\mathrm{p}=2)$ model is based), and the desired confidence level for bounding the estimated mean density when the $\mathrm{WL}$ is $\mathrm{WL}_{\mathrm{i}}$ is represented by $100(1-\alpha) \%$,

- the inverse product-moment matrix is represented by $\left(\mathbf{X}^{\mathrm{T}} \mathbf{X}\right)^{-1}$ where the product moment matrix contains information describing the data for the independent variable (i.e., the WLs) used to generate the regression equation (the WL values of this matrix are given as part of the information of Table 2),

- $\underline{\mathrm{c}}_{0}$ is the vector, $\left[1 \mathrm{WL}_{\mathrm{i}}\right.$ ], containing the $\mathrm{WL}_{\mathrm{i}}$,

- $\mathrm{z}_{1-\alpha_{0}}$ represents the one-sided $100\left(1-\alpha_{0}\right) \%$ percentile point from the standard normal distribution representing the $1-\alpha_{0}$ fraction of the model predictions to be covered, and

- $\quad \chi_{\alpha / 2, \mathrm{n}-\mathrm{p}}^{2}$ represents the lower (i.e., $\left.100(\alpha / 2) \%\right)$ percentile point of the $\chi^{2}$ distribution with $(n-p)$ degrees of freedom, used to establish an upper bound for the variance of the densities around the fitted line.

However, using equation (1) to bound the density for the SB8 glass system based solely on the results from fitting the SO regression line of Figure 2 would be inadequate to capture the impact of the variation in sludge composition on density. To quantify this variation, the densities of all of the EVbased glasses are utilized as well as the SO and ARP glasses at 36\% WL. Figure 3 provides a histogram and descriptive statistics for these data. From this figure, the standard deviation of the density values for the EV-based glasses is given by $0.009901 \mathrm{~g} / \mathrm{cm}^{3}$. This standard deviation includes variation in the densities due to differences in sludge composition. Substituting the $0.009901 \mathrm{~g} / \mathrm{cm}^{3}$ value in the computation of equation (1) for the RMSE value instead of the $0.001169 \mathrm{~g} / \mathrm{cm}^{3}$ value from Figure 2 provides a more representative UTL for the relationship between density and WL for

\footnotetext{
${ }^{a}$ The UTLs were determined using the approach provided on page 124 of Miller. The notation $\mathrm{x} \% \mathrm{y} \%$ UTL, such as 95\%/95\% UTL, will be used to represent these UTLs. The notation refers to the $\mathrm{x} \%$ confidence tolerance interval with y\% of the densities (in this case) being less than the UTL. The approach is based on a normal distribution.
} 
the SB8 glass system since it accounts for variations in the density values due to variations in the sludge composition. As this substitution is made in equation (1), the number of degrees of freedom, 13, for the 0.009901 value from Figure 3 is also used for the determination of the radical involving the $\chi^{2}$ distribution as well as the degrees of freedom for the $\chi^{2}$ distribution itself.

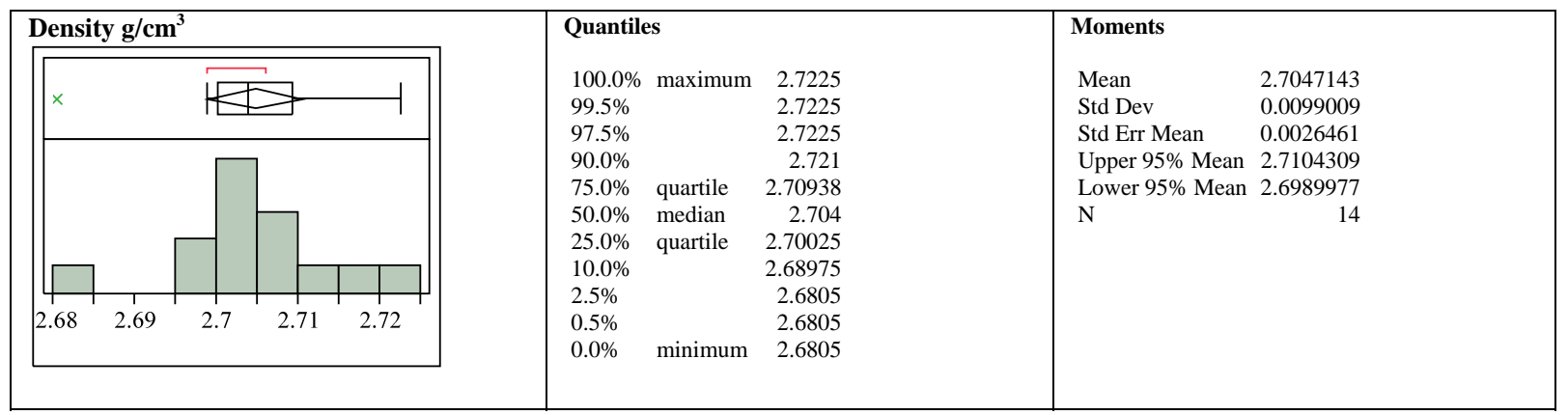

Figure 3. Histogram and Descriptive Statistics for the Densities of SB8 VS Glasses at 36\% WL.

Based upon the information in Figure 2 and Figure 3 and utilizing equation (1), a 99\% upper tolerance limit (using 0.009901 for the value of $s$ in the equation) was developed to provide an upper bound at 99\% confidence for the densities of SB8 glasses at WLs from 32 to 40\%. Table 3 summarizes the predicted (mean) density as a function of WL for the linear model, and the 99\%/99\% UTL.

Table 3. Predicted Densities as a Function of WL for the Linear Fit with $99 \% / 99 \%$ UTLs.

\begin{tabular}{||c|c|c||}
\hline WL & $\begin{array}{c}\text { Predicted Mean } \\
\text { Density }\left(\mathbf{g} / \mathbf{c m}^{\mathbf{3}}\right)\end{array}$ & $\begin{array}{c}\mathbf{9 9 \% / 9 9 \%} \\
\mathbf{U T L}\end{array}$ \\
\hline 32 & 2.675 & 2.779 \\
\hline 34 & 2.691 & 2.777 \\
\hline 36 & 2.707 & 2.786 \\
\hline 38 & 2.723 & 2.810 \\
\hline 40 & 2.739 & 2.843 \\
\hline
\end{tabular}

It is recommended that DWPF utilize the 99\%/99\% UTL values given in Table 3 as the upper bounds for the densities of SB8 glasses at the WLs indicated to assess the fissile concentration in this glass system. 


\subsection{SUMMARY}

DOE-SR has provided direction to SRR to maintain fissile concentration in glass below $897 \mathrm{~g} / \mathrm{m}^{3}$. In support of that guidance, SRNL provided a technical basis and a supporting Microsoft ${ }^{\circledR}$ Excel $^{\circledR}$ spreadsheet for the evaluation of fissile loading in SB5 glass based on the Fe concentration in glass as determined by the measurements from the SME acceptability analysis. SRR has since requested that the necessary density information be provided to allow SRR to update the inputs to the Excel ${ }^{\circledR}$ spreadsheet so that it may be used to maintain fissile concentration in glass below $897 \mathrm{~g} / \mathrm{m}^{3}$ during the processing of SB8.

One of the primary inputs into the fissile loading spreadsheet includes a bounding density for SB8based glasses. Based on the measured density data of the SB8 variability study glasses, it is recommended that SRR utilize the 99\%/99\% UTL density values given below as bounding densities for SB8 glasses to assess the fissile concentration in this glass system at the WLs as indicated. It should be noted that no changes are needed to the underlying structure of the Excel ${ }^{\circledR}$-based spreadsheet to support fissile assessments for SB8. However, SRR should update the other key inputs to the spreadsheet that are based on fissile and Fe concentrations reported from the SB8 Waste Acceptance Product Specifications (WAPS) sample.

\begin{tabular}{||c|c||}
\hline WL & $\begin{array}{c}\mathbf{9 9 \% / 9 9 \%} \\
\text { UTL }\end{array}$ \\
\hline 32 & 2.779 \\
\hline 34 & 2.777 \\
\hline 36 & 2.786 \\
\hline 38 & 2.810 \\
\hline 40 & 2.843 \\
\hline
\end{tabular}




\subsection{REFERENCES}

1. L.D. Olson, "Fissile Isotope Glass Concentration in Defense Waste Processing Facility (DWPF) Canisters,” LWO-EVP-2008-00043, Washington Savannah River Company, Aiken, South Carolina, 2008.

2. T.B. Edwards and D.K. Peeler, "Estimation of Fissile Mass Loadings from Iron Concentrations in SB5 Glasses," SRNL-TR-2009,00258, Revision 0, Savannah River National Laboratory, Aiken, South Carolina, 2009.

3. T.B. Edwards and D.K. Peeler, "Evaluation of Glass Density to Support the Estimation of Fissile Mass Loadings from Iron Concentrations in SB6 Glasses,” SRNL-STI-2010-00757, Revision 0, Savannah River National Laboratory, Aiken, South Carolina, 2010.

4. T.B. Edwards and D.K. Peeler, "Evaluation of Glass Density to Support the Estimation of Fissle Mass Loadings from Iron Concentrations in SB7a Glasses,” SRNL-STI-2011-00512, Revision 0, Savannah River National Laboratory, Aiken, South Carolina, 2011.

5. T.B. Edwards and D.K. Peeler, "Evaluation of Glass Density to Support the Estimation of Fissle Mass Loadings from Iron Concentrations in SB7b Glasses,” SRNL-STI-2012-00007, Revision 0, Savannah River National Laboratory, Aiken, South Carolina, January 2012.

6. A. Samadi, "Sludge Batch 8 Frit Optimization,” Savannah River Remediation, Aiken, South Carolina, HLW-DWPF-TTR-2012-0011, Revision 0, 2012.

7. W.K. Kot, I.L. Pegg, D.K. Peeler, and T.B. Edwards, "Product Consistency Test Results for Sludge Batch 8 Glass Variability Study,” VSL-13L2580-2, Vitreous State Laboratory, The Catholic University of America Washington, DC, February 2013.

8. W.K. Kot, I.L. Pegg, D.K. Peeler, and T.B. Edwards, "Sludge Batch 8 Variability Study with Frit 803,” VSL-13R2580-1, Vitreous State Laboratory, The Catholic University of America, Washington, DC, March 2013.

9. $\quad$ D.K. Peeler and T.B. Edwards, "Frit Recommendation for Sludge Batch 8,” SRNL-L31002012-00195, Savannah River National Laboratory, Aiken, South Carolina, November 2012.

10. W.K. Kot, H. Gan, and I.L. Pegg,"Test Plan: Sludge Batch 8 Glass Variability Study," VSL12T2580-1, Vitreous State Laboratory, The Catholic University of America Washington, DC, February 2012.

11. SAS Institute, Inc., JMP Version 9.0.0, SAS Institute, Inc., Cary, North Carolina, 19892010 .

12. "Test Method for Density of Glass by Bouyancy at Room Temperature,” VSL Procedure TPI-GDB, Vitreous State Laboratory, The Catholic University of America, Washington, DC, March 2013.

13. NIST, "Certificate of Analysis. Standard Reference Material. 1826b: Soda Lime Glass Mass Density Standard,” National Institute of Standards and Technology, Gaitherburg, MD, December 2006. 
14. NIST, “Certificate of Analysis. Standard Reference Material 1827a: Lead Silica Glass Mass Density Standard,” National Insititute of Standards and Technology, Gaithersburg, MD, February 1996.

15. R.G. Miller, Simultaneous Statistical Inference, Second Edition ed. Springer-Verlag, New York, 1989. 
This page intentionally left blank. 


\section{Electronic Distribution by E-Mail to the Following}

\section{SRS Distribution:}

\begin{tabular}{|c|c|}
\hline Name: & Location: \\
\hline Patrick R. Jackson & 703-46A \\
\hline Sharon Marra & 773-A \\
\hline Damon Click & 999-W \\
\hline Patricia Lee & $703-41 \mathrm{~A}$ \\
\hline Gene Shine & 703-41A \\
\hline David Peeler & 999-W \\
\hline Tommy Edwards & 999-W \\
\hline Kevin Fox & 999-W \\
\hline Eric Freed & $704-S$ \\
\hline Dave Sherburne & $704-S$ \\
\hline Kishor Shah & $704-S$ \\
\hline Karthik Subramanian & 766-H \\
\hline Jonathan Bricker & 704-27S \\
\hline John Iaukea & 704-30S \\
\hline Jeff Ray & $704-S$ \\
\hline Robert Hinds & $704-S$ \\
\hline Terri Fellinger & 704-26S \\
\hline Amanda Shafer & 704-27S \\
\hline Mason Clark & 704-27S \\
\hline Helen P. Boyd & 704-27S \\
\hline Hank Elder & $704-24 S$ \\
\hline Bill Holtzscheiter & 704-15S \\
\hline Wayne Drown & $773-41 \mathrm{~A}$ \\
\hline
\end{tabular}

\section{CUA/VSL Distribution:}

\begin{tabular}{|l|l|}
\hline Name: & Location: \\
\hline Wing Kot & CUA/VSL \\
\hline \hline Ian Pegg & CUA/VSL \\
\hline Hao Gan & CUA/VSL \\
\hline \multicolumn{1}{|l|}{} & \\
\hline & \\
\hline & \\
\hline & \\
\hline & \\
\hline & \\
\hline
\end{tabular}

\section{ES Distribution:}

\begin{tabular}{|l|l|}
\hline Name: & Location: \\
\hline \hline Brad Bowan & ES \\
\hline \hline Glenn Diener & ES \\
\hline Innocent Joseph & ES \\
\hline \multicolumn{1}{|l|}{} & \\
\hline & \\
\hline & \\
\hline & \\
\hline & \\
\hline & \\
\hline
\end{tabular}

